\title{
Antimicrobial and antibiofilm potential of biosurfactants isolated from lactobacilli against multi-drug-resistant pathogens
}

\author{
Karthik Sambanthamoorthy, Xiaorong Feng, Ruchi Patel, Sneha Patel and Chrysanthi Paranavitana*
}

\begin{abstract}
Background: Biosurfactants (BS) are amphiphilic compounds produced by microbes, either on the cell surface or secreted extracellularly. BS exhibit strong antimicrobial and anti-adhesive properties, making them good candidates for applications used to combat infections. In this study, our goal was to assess the in vitro antimicrobial, anti-adhesive and anti-biofilm abilities of BS produced by Lactobacillus jensenii and Lactobacillus rhamnosus against clinical Multidrug Resistant (MDR) strains of Acinetobacter baumannii, Escherichia coli, and Staphylococcus aureus (MRSA). Cell-bound BS from both L. jensenii and L. rhamnosus were extracted and isolated. The surface activities of crude BS samples were evaluated using an oil spreading assay. The antimicrobial, anti-adhesive and anti-biofilm activities of both BS against the above mentioned MDR pathogens were determined.

Results: Surface activities for both BS ranged from 6.25 to $25 \mathrm{mg} / \mathrm{ml}$ with clear zones observed between 7 and $11 \mathrm{~cm}$. BS of both L. jensenii and L. rhamnosus showed antimicrobial activities against A. baumannii, E. coli and S. aureus at $25-50 \mathrm{mg} / \mathrm{ml}$. Anti-adhesive and anti-biofilm activities were also observed for the aforementioned pathogens between 25 and $50 \mathrm{mg} / \mathrm{ml}$. Finally, analysis by electron microscope indicated that the BS caused membrane damage for A. baumannii and pronounced cell wall damage in S. aureus.
\end{abstract}

Conclusion: Our results indicate that BS isolated from two Lactobacilli strains has antibacterial properties against MDR strains of A. baumannii, E. coli and MRSA. Both BS also displayed anti-adhesive and anti-biofilm abilities against A. baumannii, E. coli and S. aureus. Together, these capabilities may open up possibilities for BS as an alternative therapeutic approach for the prevention and/or treatment of hospital-acquired infections.

Keywords: Anti-adhesive, Anti-biofilm, Biosurfactant, Antimicrobial, Lactobacillus jensenii, Lactobacillus rhamnosus

\section{Background}

Biosurfactants (BS) are amphiphilic compounds produced mostly by microbes on their cell surface, or secreted extracellularly and exhibit strong surface and emulsifying activities. They contain both hydrophobic and hydrophilic moieties that can reduce the surface or interfacial tension in liquids [1]. BS are complex molecules that include glycolipids, rhamnolipids, lipopeptides, polysaccharideprotein complexes, phospholipids, fatty acids and neutral lipids [2]. Unlike synthetic surfactants, BS are diverse and biodegradable, and have the potential for highly selective, specialized functions. Several BS exhibit anti-bacterial,

\footnotetext{
* Correspondence: cparanavit@hotmail.com Department of Wound Infections, Bacterial Diseases Branch, Walter Reed Army Institute of Research, 503 Robert Grant Avenue, Silver Spring, MD 20910, USA
}

anti-fungal and anti-viral activities, making them appropriate candidates to combat infections [3].

The list of known BS includes surfactin, the most powerful BS known, which is produced by Bacillus subtilis [4]. Other BS with antimicrobial activity include iturin, also produced by B. subtilis [4], mannosylerythritol lipids from Candida antarctica [5], rhamnolipids from Pseudomonas aeruginosa [6] and those isolated from probiotic bacteria Streptococcus thermophilus A and Lactococcus lactis [7-9]. Probiotic lactobacilli, which constitute an important part of natural microbiota, are recognized as potent interfering bacteria due to the production of various antimicrobial agents including BS [10]. In one study, 15 Lactobacillus strains were tested in vitro for BS production. It was found that all released 
surface active components during their mid-exponential and stationary growth phases [6].

Another valuable attribute of BS is their use as antiadhesive/anti-biofilm agents $[3,11]$ as shown previously in the lack of adhesion of Enterococcus faecalis to glass with an adsorbed BS layer from Lactobacillus acidophilus RC14 or Lactobacillus fermentum B54 [12].

Biofilms are conglomerations of bacterial cells protected by self-synthesized extracellular polysaccharide matrices (EPS). Biofilm infections are extremely challenging to treat because antimicrobials are less effective than planktonic cells $[13,14]$, thus making clearance more challenging. The presence of biofilms causes numerous problems in the field of medicine, interfering with clinical therapy of chronic and wound-related infections as well as persistent infections of various indwelling medical devices [15]. Although numerous strategies have been established and are currently in use to control biofilms, the pursuit for novel, natural, and effective antibiofilm agents still continues [16-18].

In recent years, the use of BS as alternatives to control biofilms has been explored extensively [19-21]. BS have been shown to modify the surface properties of bacterial cells and reduce their adhesive properties [4]. In addition, BS produced by bacteria have been shown to interfere with biofilm development and cell to cell communication [22-24].

Studies in the past have demonstrated the ability of probiotic bacteria $L$. acidophilus-derived BS to inhibit staphylococcal biofilm development and also induce its dispersion [25]. BS produced by probiotic lactobacilli have been shown to reduce adhesion of pathogenic bacteria to glass, silicone rubber, surgical implants, and voice prostheses $[8,12,26,27]$. It is believed that when BS is applied to a substratum surface, it modifies its hydrophobicity, interfering in the microbial adhesion and desorption processes $[28,29]$. Consequently, prior application of BS on catheters and other medical insertion materials may be used as a preventive strategy to delay the onset of pathogenic biofilm growth of MDR bacteria on wounds, medical insertion materials and inert surfaces in the hospital environment $[8,12,25-27,30]$. Thus, the prevention of biofilm formation or disruption by natural lactobacilli-derived agents was tested in these in vitro studies as a possible approach leading to novel antimicrobials.

The aims of this study were to determine the antimicrobial, anti-adhesive, and anti-biofilm activities of cell-bound BS isolated from $L$. jensenii and L. rhamnosus against several clinical isolates of multidrug-resistant pathogens.

\section{Results}

\section{Oil spreading assay}

The oil spreading assay was utilized to study the surface activities of crude BS. This assay is rapid, and is highly sensitive to surface active compounds [31,32]. Both $L$. jensenii and $L$. rhamnosus strains demonstrated oil displacement activity in motor oil. The oil displacement activity, as measured by the area of the clear zone on the oil-water surface, increased with an increase in the concentration of BS (Table 1).

\section{Antimicrobial assay with BS}

The crude BS of both $L$. jensenii and L. rhamnosus were tested against two clinical isolates of MDR A. baumannii, E. coli and S. aureus. We found both BS to be effective in killing all three MDR pathogens at $50 \mathrm{mg} / \mathrm{ml}$ (Table 2). $L$. jensenii BS exhibited almost 100\% activity against all the strains tested (Table 2). The activity of L. rhamnosus ranged from $96-97 \%$ against A. baumannii and 72-85\% against $E$. coli. For $S$. aureus strains UAMS-1 and MRSA respectively, activity was between 80 and $93 \%$ respectively (Table 2).

\section{Impact of BS on bacterial attachment to abiotic surface}

Biofilm formation is a complex process that generally involves three stages: (1) primary adhesion to surfaces, (2) accumulation of multilayered clusters of cells, and (3) detachment. Because binding of host proteins is a major contributor to primary adhesion, it was important to test initial adherence to surfaces that were coated with

Table 1 Diameter $(\mathrm{mm})$ of clearing zones on the oil surface obtained from oil spreading assay with different concentrations of crude biosurfactant

\begin{tabular}{lcccc}
\hline Sample & PBS & Surfactin & $\begin{array}{c}\text { Crude biosurfactant } \\
\text { L. rhamnosus }\end{array}$ & $\begin{array}{c}\text { Crude biosurfactant } \\
\text { L. jensenii }\end{array}$ \\
\hline $50 \mathrm{mg} / \mathrm{ml}$ & 0.0 & $15.0 \pm 1.0$ & $6.8 \pm 0.5$ & $7.6 \pm 0.5$ \\
$25 \mathrm{mg} / \mathrm{ml}$ & 0.0 & $15.0 \pm 1.0$ & $6.0 \pm 1.4$ & $6.0 \pm 1.7$ \\
$12.5 \mathrm{mg} / \mathrm{ml}$ & 0.0 & $14.6 \pm 0.5$ & $5.3 \pm 0.5$ & $5.6 \pm 1.1$ \\
$6.25 \mathrm{mg} / \mathrm{ml}$ & 0.0 & $13.0 \pm 0.5$ & $4.1 \pm 0.1$ & $3.8 \pm 0.2$ \\
\hline
\end{tabular}

PBS was used as a negative control with a clearing zone diameter of $0.0 \mathrm{~mm}$. Surfactin was used as a positive control. Results shown are the average of \pm SD of three experiments performed in triplicate. 
Table 2 Antimicrobial activity of the crude biosurfactant from L. jensenii (BSLJ) and L. rhamnosus (BSLR) against MDR pathogens

\begin{tabular}{|c|c|c|c|c|c|c|c|}
\hline & AB5075 & AB5711 & EC438 & EC433 & MRSA & S. aureus UAMS-1 & KP4640 \\
\hline BSLJ & 99.0 & 100.00 & 99.00 & 99.00 & 99.0 & 99.0 & 99.9 \\
\hline SD & 0.01 & 0 & 0.05 & 0.43 & 0.03 & 0.04 & 0.02 \\
\hline BSLR & 96.35 & 97.85 & 72.34 & 85.34 & 93.27 & 80.54 & 91.6 \\
\hline SD & 2.96 & 2.16 & 2.36 & 6.21 & 3.15 & 7.11 & 1.96 \\
\hline
\end{tabular}

Results are from 3 independent preparations of $\mathrm{BS} .(\mathrm{AB}=A$. baumannii; $\mathrm{EC}=E$. coli; $\mathrm{MRSA}=$ methicillin resistant $\mathrm{S}$. aureus, $\mathrm{KP}=$ Klebsiella pneumoniae and $\mathrm{SD}=$ Standard deviation). Biosurfactants were tested at $50 \mathrm{mg} / \mathrm{ml}$ concentration. Numbers are represented and percent reduction in cell numbers when treated with BS.

plasma. Experiments were performed to determine the stage at which BS disrupts biofilm formation. Using an adherence assay, the ability of two BS to inhibit the cell attachment in the presence of host proteins was measured by coating the plates with human plasma. After various concentrations of BS ranging from $25-50 \mathrm{mg} / \mathrm{ml}$ were tested, it was found that the two BS significantly impaired the attachment of A. baumannii and E. coli at $50 \mathrm{mg} / \mathrm{ml}$ (Figure 1). S. aureus adherence to abiotic surfaces was disrupted at concentrations between 25 and $50 \mathrm{mg} / \mathrm{ml}$ (Figure 1).

\section{Impact of BS on biofilm development}

Next, it was determined if the static biofilm assay could show whether both BS possessed anti-biofilm activity against $A$. baumannii, E. coli and S. aureus. The BS produced by both $L$. jensenii and $L$. rhamnosus significantly reduced biofilm development by $A$. baumannii and $E$. coli at $50 \mathrm{mg} / \mathrm{ml}$ (Figure 2). Furthermore, the two BS

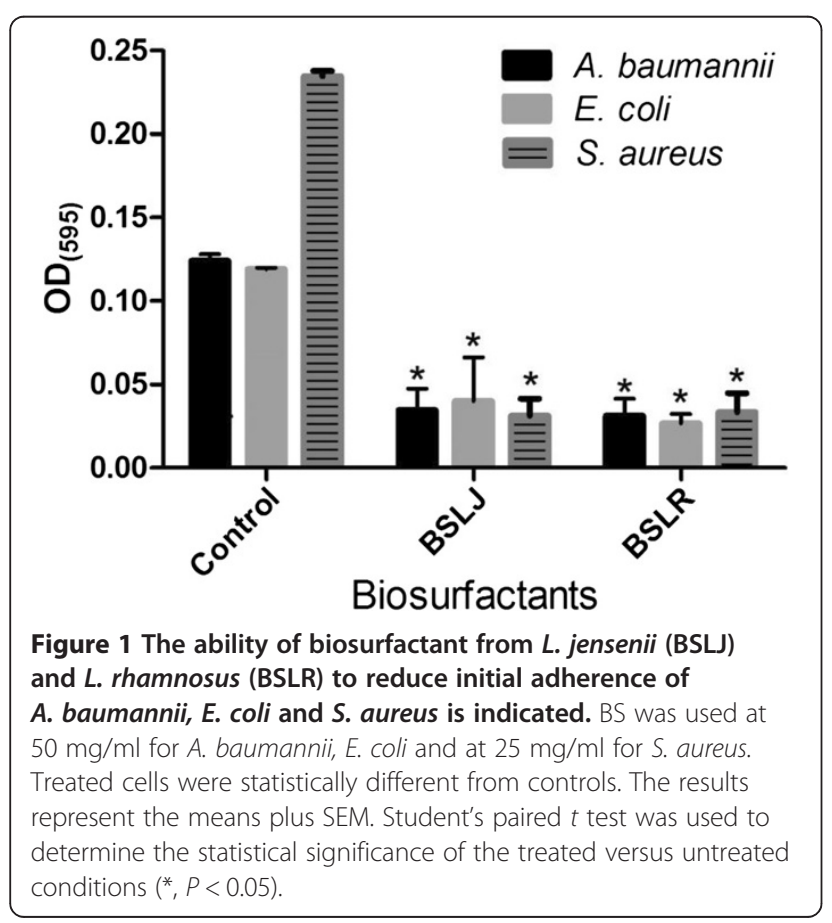

significantly inhibited $S$. aureus biofilms at both concentrations of $25 \mathrm{mg} / \mathrm{ml}$ respectively (Figure 2).

\section{Dispersion of preformed biofilms by BS}

In the experiments thus far, the BS were added concurrently with inoculation of bacteria. To determine if these compounds dispersed preformed biofilms, A. baumannii and $E$. coli biofilms were developed on MBEC pegs, and then exposed to varying concentrations of $\mathrm{BS}$ in fresh media for varying time intervals. After removal of the pegs, the amounts of bacteria that remained on the pegs were quantified by crystal violet staining. Compared to the controls, preformed A. baumannii and E. coli biofilms treated with BS at $100 \mathrm{mg} / \mathrm{ml}$ for $1 \mathrm{hr}$ did not produce any dispersion effect. However, when biofilms were exposed for longer durations ( $18 \mathrm{hrs}$ ), an increased biofilm dispersion was observed (Figure 3). Furthermore, an increase in dispersion was also observed for S. aureus biofilms when exposed to the BS at concentrations of $50 \mathrm{mg} / \mathrm{ml}$ for $18 \mathrm{hrs}$ respectively (Figure 3).

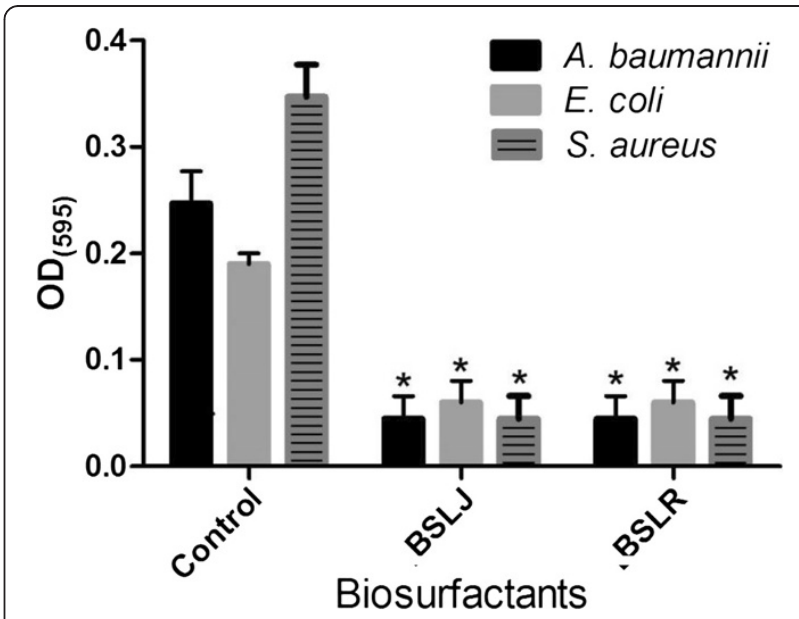

Figure 2 The ability of biosurfactants from L. jensenii (BSLJ) and $L$. rhamnosus (BSLR) in reducing biofilm formation in A. baumannii, E. coli and S. aureus is indicated. BS was used at $50 \mathrm{mg} / \mathrm{ml}$ for A. baumannii, E. coli and at $25 \mathrm{mg} / \mathrm{ml}$ for S. aureus. Treated cells were statistically different from controls. The results represent the means plus SEM. Student's paired $t$ test was used to determine the statistical significance of the treated versus untreated conditions $\left({ }^{*}, P<0.05\right)$. 


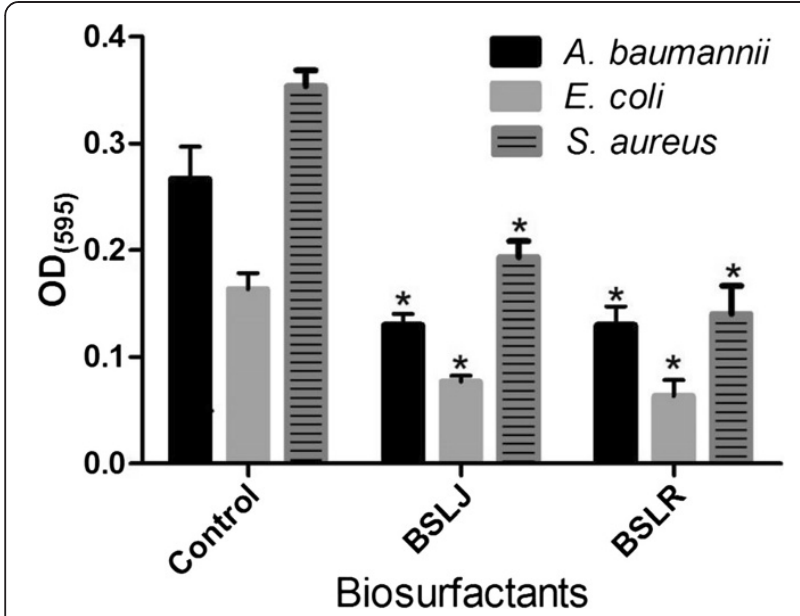

Figure 3 The ability of biosurfactants from $L$. jensenii (BSLJ) and $L$. rhamnosus (BSLR) in dispersing biofilm formation in A. baumannii, E. coli and S. aureus is indicated. BS was used at $100 \mathrm{mg} / \mathrm{ml}$ for A. baumannii, E. coli and at $50 \mathrm{mg} / \mathrm{ml}$ for S. aureus. Treated cells were statistically different from controls. The results represent the means plus SEM. Student's paired $t$ test was used to determine the statistical significance of the treated versus untreated conditions ( $\left.{ }^{*}, P<0.05\right)$

\section{Cytotoxicity assays for BS in eukaryotic cells}

Results from the cell-mediated cytotoxicity assay are presented in Figure 4. Human A549 lung epithelial cells were treated with BS from both Lactobacilli strains at various concentrations $(25,50,100$ and $200 \mathrm{mg} / \mathrm{ml})$ for 24 h. Cytotoxicity was determined by LDH release according to the manufacturer's instructions and the total cell number assay (Figure 4). Concentrations of $25-100 \mathrm{mg} / \mathrm{ml}$ showed no toxicity. Both BS showed very low toxicity levels at $200 \mathrm{mg} / \mathrm{ml}$ (Figure 4).

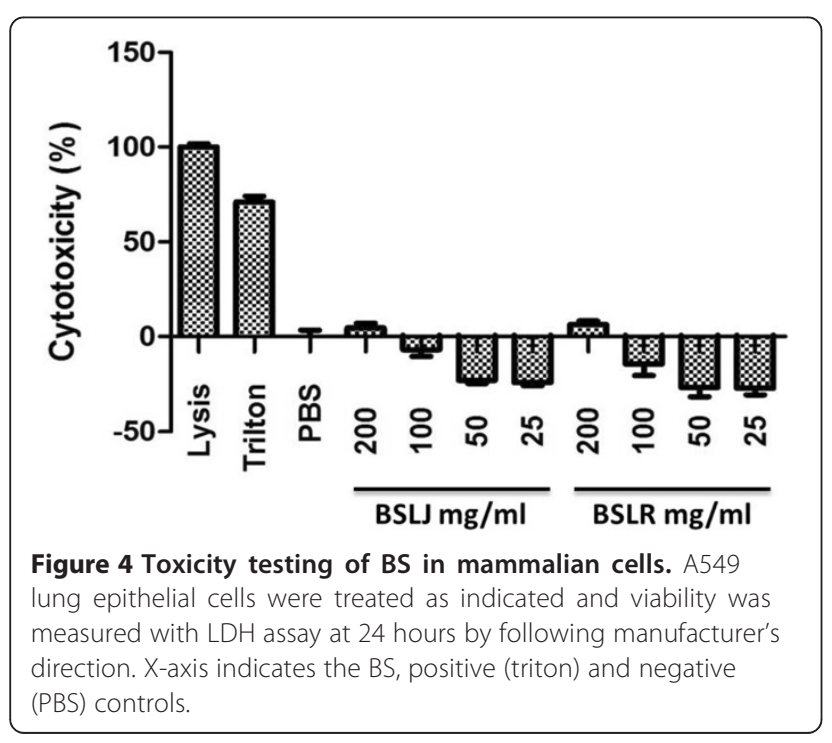

Transmission electron microscopy

TEM was used to evaluate the ultra-structural morphological alterations exerted to $A$. baumannii and $S$. aureus in the presence of BSLR. We chose A. baumannii 5075 and $S$. aureus UAMS-1 strains to represent a Gram negative and Gram positive pathogen for analysis. Untreated cells of the both A. baumannii and S. aureus showed a normal cell shape with an intact structure of the cell wall, inner membrane and outer membrane. The images of the A. baumannii samples treated with L. rhamnosus BS were markedly different to those of the untreated cells. Several BSLR treated A. baumannii cells had their membranes damaged at certain areas of the bacterial cell with accumulation of dense substance (Figure 5). Surprisingly we also found that L. rhamnosus BS seems to cause more damage specifically to the ends of the bacterial cell (Figure 5). S. aureus cells treated with L. rhamnosus BS exhibited profound structural differences when compared to untreated cells. Several cells were observed devoid of cell walls, a phenomenon called as "ghost" cells. The dark and light areas observed in the cells were indicative of high and low electron densities respectively. Several cells were found to contain septa when compared with the control samples (Figure 5). This may be due to BS interfering with the cell division process and this is probably indicative of one of the mechanisms of action of BSLR by inhibiting the cell division.

\section{Discussion}

Here, we describe two cell-associated biosurfactants derived from probiotic lactobacilli bacteria that possess both antibacterial activities and inhibit biofilm formation by several important drug-resistant pathogens. Although some strains of lactobacilli are known to produce surfactants, to the best of our knowledge there are no reports on the abilities of $L$. jensenii and $L$. rhamnosus BS as antibiofilm agents. The crude BS derived from aforementioned bacteria showed significant antimicrobial activities against $A$. baumannii, E. coli, MRSA and S. aureus at MIC concentrations ranging between 25 and $50 \mathrm{mg} / \mathrm{ml}$. $L$. jensenii BS showed antimicrobial activity at $25 \mathrm{mg} / \mathrm{ml}$ against all three pathogens with killing that varied from 75-99.9\%, and at $12.5 \mathrm{mg} / \mathrm{ml}$, it showed $90-100 \%$ killing against MRSA. In addition, we observed similar antimicrobial activities from both BS with similar MIC concentrations against MDR Klebsiella pneumoniae (Table 2). In this study, we clearly showed the effect of BS on the bacterial cells by transmission electron microscopy (Figure 5). The bacterial cell membrane appears to be the target of BS activity and subsequent microbicidal activity of BS may be due to the leakage of cellular contents. BS that exhibit antimicrobial activity has been previously described [33-35], but to date there have been very few studies on the activity of BS isolated from lactobacilli 


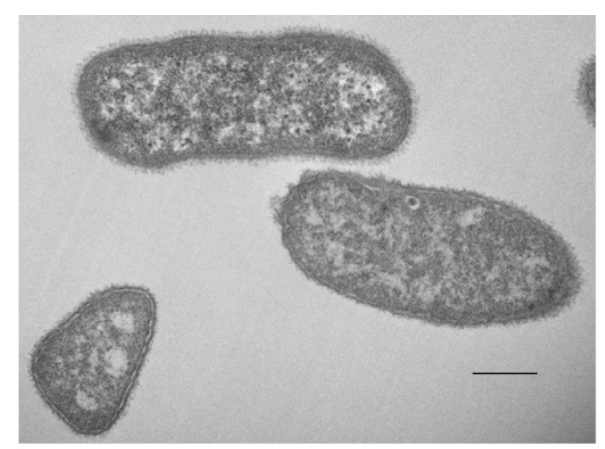

A. baumannii

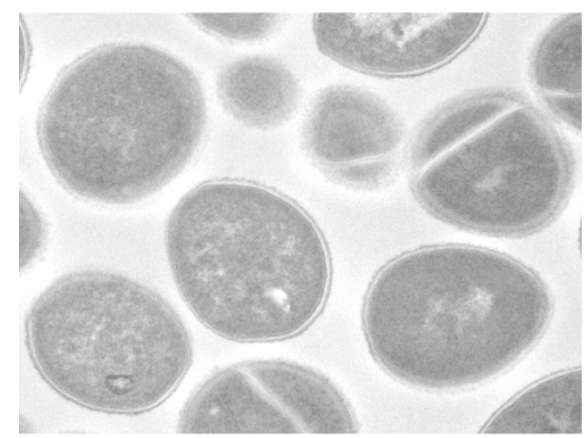

S. aureus (High magnification)

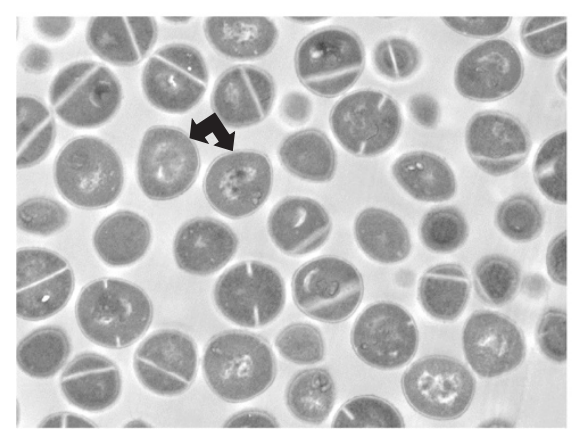

S. aureus (Low magnification)

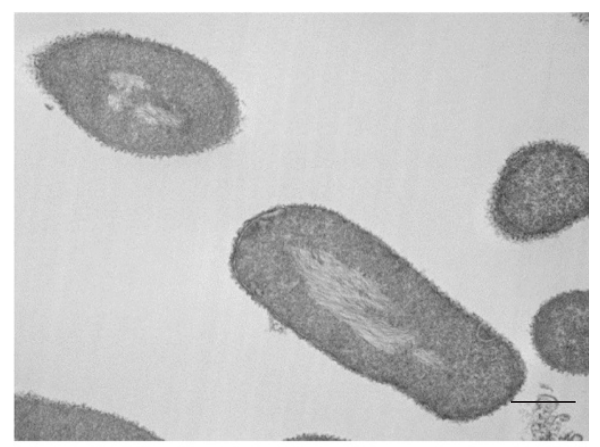

A. baumannii + BSLR

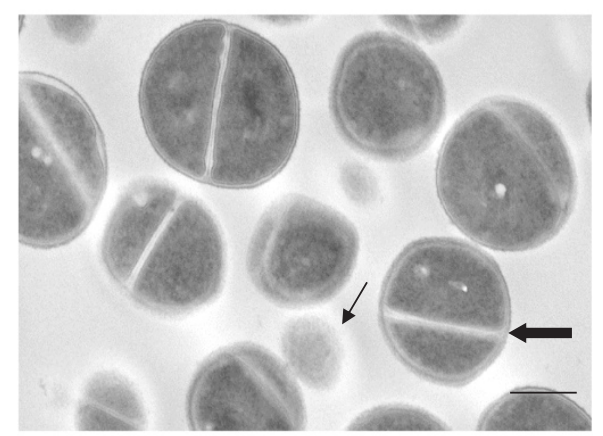

S. aureus + BSLR (High magnification)

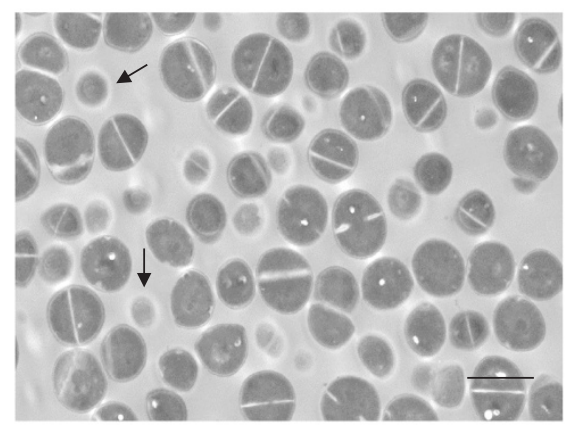

S. aureus + BSLR (Low magnification)

Figure 5 Transmission electron microscope details on A. baumanni and S. aureus treated with BSLR. A. baumannii and S. aureus grown in the presence and absence of BSLR ( 4 X MIC) were imaged at $3 \mathrm{~h}$ post incubation. Photographs were taken at a magnification of $\times 15000$. The thick arrow indicates septum formation and the thin arrow indicates the ghost cells appearance respectively. For $S$. aureus, images were also acquired at lower magnification of $\times 8000$, where a visible difference was seen between treated and untreated samples. BSLR treated S. aureus showed many more ghost cells (thin arrows) and cells without visible intracellular organelles compared to untreated cells (thick double arrows).

$[8,9,28,29,33]$. The antimicrobial results generated from our studies were similar to the results from crude BS studies on L. paracasei ssp. paracasei A20 and L. lactis, which completely inhibited the growth of several microorganisms at concentrations ranging between 25 and $100 \mathrm{mg} / \mathrm{ml}[8,9,33]$. In addition, BS exhibited excellent anti-adhesive properties against $S$. aureus, A. baumannii and $E$. coli, as evidenced in our adhesion based assays.

Next, the biofilm inhibition and dispersal capability of BS against the above mentioned three pathogens was evaluated. The crude BS isolated in this study exhibited very good anti-biofilm activities against select microorganisms. In the past, several studies have documented the anti-biofilm activity of BS isolated from different bacteria [19-21]. Preformed biofilms of all the three bacteria tested in microtiter plate wells were effectively disrupted by the BS. The BS dispersed all three bacteria when exposed for longer durations. The inhibition of biofilms using surfactants has been reported previously [12]. In addition, BS have been shown to disperse biofilms 
of Bordetella bronchiseptica and B. pumilus [19,22]. The increased anti-biofilm and dispersal ability of the BS currently being investigated may be due to the two important properties that it displays, namely, antimicrobial and surfactant activity. Previous studies with a BS isolated from Lactobacillus spp. have only demonstrated its antimicrobial and anti-adhesive properties [33]. Here we report for the first time BS isolated from lactobacillus also displaying anti-biofilm properties. Both L. jensenii and L. rhamnosus BS were able to significantly reduce biofilm development by $A$. baumannii, E. coli and S. aureus.

The use and applications of BS in the medical field has increased considerably in the last years. The impact of BS in bacterial adhesion and desorption has been widely discussed, and subsequent adsorption of these BS to solid abiotic surfaces could prove an effective strategy to reduce bacterial adhesion, thereby combating microbial colonization in both medicine and industry [7,30,36,37]. The anti-biofilm and anti-adhesive activities of the BS observed against several pathogens in our studies opens up the possibility of using them to coat a variety of medical surfaces to drastically reduce microbial colonization.

In conclusion, in this work we have demonstrated the antimicrobial, anti-biofilm, and anti-adhesive properties of the crude BS isolated from L. jensenii against several pathogenic MDR bacteria. We also observed that addition of both BS at effective concentrations to eukaryotic cells resulted in low cytotoxicity (Figure 4), suggesting the safety of these compounds for topical delivery. Biofilm encroachment on biomaterial is an extremely important concern post-surgery. Hence, our results open the possibility of using BS-modified materials for the construction of biofilm-resistant medical implantable devices, given its broad-spectrum activity against both Gram-positive and Gram-negative bacterial strains. BS exhibits potential as a new therapeutic strategy to inhibit biofilm formation. Because the increased prevalence of antibiotic-resistant bacteria generates a need for alternate and novel strategies to combat biofilms, we believe that co-administering antibiotics with anti-biofilm agents that possess surface activities such as BS may form the basis of future clinical protocols against biofilm-based infections.

Currently, experiments are underway to characterize the crude fractions of the surfactants by high performance liquid chromatography. We have identified certain fractions that exhibit excellent antimicrobial activities against $A$. baumanni, S. aureus, K. pneumoniae and E. coli. These fractions are being further analyzed by mass spectrometry and Matrix assisted laser desorption/ionization- time of flight (MALDI-TOF) to identify the active component/s.

\section{Conclusion}

The BS produced by $L$. jensenii and L. rhamnosus showed antiadhesive, antimicrobial and antibiofilm activities against several MDR bacteria, such as E. coli, A. baumannii and $S$. aureus, which are prominent biofilm formers on wounds, medical implants and industrial surfaces. Antiadhesive and antimicrobial activities were seen between 25-100 mg/ml. MBEC based biofilm assays confirmed the inhibitory action of BS on biofilm development at concentrations ranging $25-50 \mathrm{mg} / \mathrm{ml}$. In addition, BS dispersed preformed biofilms of $A$. baumannii and $S$. aureus at concentrations ranging $50-100 \mathrm{mg} / \mathrm{ml}$. Due to its surface tension reduction properties, BS can be used to coat medical surfaces to prevent microbial colonization by variety of bacteria causing indwelling device associated infections.

\section{Methods}

\section{Strains and growth conditions}

L. jensenii 25258 and L. rhamnosus 7469 were purchased from ATCC (ATCC, Manassas, VA, USA). The strains were stored at $-80^{\circ} \mathrm{C}$ in MRS broth (Difco, Sparks, MD, USA) containing $20 \%(\mathrm{v} / \mathrm{v})$ glycerol. Multi-drug-resistant test strains were stored at $-80^{\circ} \mathrm{C}$ in the appropriate media with $15 \%$ (v/v) glycerol until use. E. coli strains EC433, EC438, A. baumannii strains AB5075, AB5711 were cultured in LB broth and S. aureus clinical isolate 243 (MRSA) and UAMS-1 in trypticase soy broth. All the strains were grown at $37^{\circ} \mathrm{C}$ for $4 \mathrm{~h}$ in the appropriate media, and were washed in PBS $2 \mathrm{X}$ and resuspended in $\mathrm{PBS}$ to the appropriate OD at $600 \mathrm{~nm}$ for testing.

\section{BS production and isolation}

To isolate cell-associated BS, the following protocol was pursued according to previously published methods used by several other investigators for lactobacilli BS $[8,10,33]$. For crude BS production by L. jensenii 25258, $1200 \mathrm{ml}$ of MRS culture broth was inoculated with $10 \mathrm{ml}$ of an overnight culture of $L$. jensenii and incubated for $48 \mathrm{~h}$ at $37^{\circ} \mathrm{C}$ at $120 \mathrm{RPM}$ on a shaker. For L. rhamnosus, $1200 \mathrm{ml}$ culture of MRS broth was inoculated with $10 \mathrm{ml}$ of an overnight culture and incubated for $48 \mathrm{~h}$ at $33^{\circ} \mathrm{C}$ without shaking. After 48 hours, cell pellets were collected by centrifugation $\left(10000 \times \mathrm{g}, 10 \mathrm{~min}, 10^{\circ} \mathrm{C}\right)$, washed twice in demineralized water, and re-suspended in $100 \mathrm{ml}$ of PBS. This solution was gently stirred at room temperature for $2 \mathrm{~h}$ to release the cell-bound BS. After 2 hours, bacteria were removed by centrifugation and the supernatant liquid was collected by filtering through a 0.22 um filter. The filtered sterile supernatant was lyophilized. The freeze-dried BS was stored at $-20^{\circ} \mathrm{C}$, and resuspended in deionized water at $100 \mathrm{mg} / \mathrm{ml}$ (w/vol).

\section{Antimicrobial assay with BS}

The antimicrobial activities of L. jensenii and L. rhamnosus crude BS against several pathogens were determined in 96-well tissue culture plates by a modified microdilution 
method [33]. Briefly, $100 \mu \mathrm{l}$ of sterile, double-strength MHB broth was placed into the first column of the 96well microplate and $100 \mu \mathrm{l}$ of sterile, single-strength $\mathrm{MHB}$ broth in the remaining wells. Subsequently, $100 \mu \mathrm{l}$ of BS solution in PBS $(100 \mathrm{mg} / \mathrm{ml})$ was added to the first column of the microplate and mixed with the medium; this resulted in a BS concentration of $50 \mathrm{mg} / \mathrm{ml}$, and $100 \mu \mathrm{l}$ was transferred serially to the subsequent wells, resulting in two-fold dilutions. Columns without BS served as positive growth controls. All the wells were inoculated with $100 \mu \mathrm{l}$ of $10^{8} \mathrm{CFU}$ from each of the test strains from a log phase culture. Microtiter plates were covered and incubated for $24 \mathrm{~h}$ under the appropriate growth conditions for each microorganism. Three independent preparations of crude BS were tested in duplicate. The contents of each well were plated onto LB agar plates with appropriate dilutions, and CFU were enumerated the next day. Percent killing was calculated as 1 - (treated/control $\times 100)$.

\section{Oil spreading assay to determine surfactant activity}

For the oil spreading assay, $50 \mathrm{ml}$ of demineralized water was added to a $150 \mathrm{~mm}$ diameter Petri dish and $20 \mu \mathrm{l}$ of motor oil was added to the surface of the water. Ten microliters of crude BS from either L. jensenii or L. rhamnosus, dissolved in deionized water was then added to the surface of the oil at concentrations ranging from 6.25 to $50 \mathrm{mg} / \mathrm{ml}$. Surfactin was used as a positive control at the same concentrations, and a negative control was included with PBS. The diameters of clear zones of triplicate assays from the same sample were determined.

\section{Cytotoxicity assay}

The human lung epithelial cell line (A549) was used in this study. The cytotoxicity of the crude BS from both Lactobacilli was evaluated on eukaryotic cells by the release of lactate dehydrogenase (LDH) and total cell number assay. The LDH cytotoxicity assay was performed according to the manufacturer's guidelines (CytoTox 96 Non-Radioactive Cytotoxicity Assay, Promega, Madison, WI, USA). After the addition of the crude BS at different concentrations for $24 \mathrm{~h}$, the cell culture medium was collected for LDH measurement after lysis of cells. An aliquot of $50 \mu \mathrm{l}$ cell medium was used for LDH activity analysis and the absorption was measured using a UVvisible spectrophotometer. Percentage cytotoxicity was calculated as the percentage of LDH released compared to untreated cells. All experiments were repeated three times, each in triplicate.

\section{Assessment of biofilm formation}

Biofilm formation was measured under two static conditions using a quantitative crystal violet assay. BS was added to the wells that contained the media and bacterial cells. BS were used at $25-50 \mathrm{mg} / \mathrm{ml}$ concentrations in final total volume not exceeding $165 \mu \mathrm{l}$, the volume at which the biofilms develop well in the MBEC biofilm assay. Biofilms of $A$. baumannii were developed on polystyrene 96-well and MBEC (Biosurface Technologies, Bozeman, MT, USA) as described previously by Sambanthamoorthy, 2012 [38]. Briefly, cultures grown overnight were standardized to an $\mathrm{OD}_{595}$ of 0.05 and $165 \mu \mathrm{l}$ was transferred to the wells of a 96-well polystyrene microtiter plate, and the MBEC lid was placed on top of the wells. BS were added concurrently to the wells and biofilms were grown on the pegs under shaking conditions for $24 \mathrm{~h}$. The lid was removed and the pegs were gently washed twice with $200 \mu \mathrm{l}$ of PBS to remove nonadherent cells. Adherent biofilms on the pegs were fixed with $200 \mu \mathrm{l}$ of $100 \%$ ethanol prior to staining for $2 \mathrm{~min}$ with $200 \mu \mathrm{l}$ of $0.41 \%$ (wt/vol) crystal violet in $12 \%$ ethanol (Biochemical Sciences, Swedesboro, NJ, USA). The pegs were washed several times with PBS to remove excess stain. Quantitative assessment of biofilm formation was obtained by the immersion of pegs in a sterile polystyrene microtiter plate which contained $200 \mu \mathrm{l}$ of $100 \%$ ethanol and incubation at room temperature for $10 \mathrm{~min}$ before the absorbance at $595 \mathrm{~nm}$ was determined. Three independent experiments were performed for each of these assays. Biofilms of $S$. aureus were developed on polystyrene 96-well plates and evaluated against the BS as previously described [39].

\section{Biofilm dispersal}

To determine if the BS could disperse preformed biofilms, bacterial biofilms were established as previously described $[38,40]$. Briefly, established biofilms were exposed to varying concentrations of the BS in fresh media for short time intervals. Adherent biofilms on the pegs were fixed with $200 \mu \mathrm{l}$ of $100 \%$ ethanol prior to staining for $2 \mathrm{~min}$ with $200 \mu \mathrm{l}$ of $0.41 \%$ (wt/vol) crystal violet in $12 \%$ ethanol (Biochemical Sciences, Swedesboro, NJ, USA). Quantitative assessment of biofilm formation was obtained by the immersion of pegs in a sterile polystyrene microtiter plate which contained $200 \mu \mathrm{l}$ of $100 \%$ ethanol; the absorbance at $595 \mathrm{~nm}$ was determined using a SpectraMax M5 microplate spectrophotometer system. Results were interpreted by the comparison of BS on treated biofilms to untreated biofilms. Experiments were performed in triplicate and three independent experiments were performed for each of these assays.

\section{Adherence of A. baumannii, E. coli and S. aureus to abiotic surfaces}

An initial adherence assay was used to measure the impact of BS on the surface binding capacity of A. baumannii, E. coli and S. aureus. The assay was performed by modifying a microtiter biofilm assay as described previously [39]. Briefly, overnight cultures of A. baumannii and S. aureus 
test strains were diluted to an absorbance value of 0.05 at $595 \mathrm{~nm}$ in fresh medium, and $200 \mu \mathrm{l}$ was added to each well (polystyrene pre-coated with human plasma) in triplicate. This was followed by adding BS at relevant concentration to be tested into the wells. Following $1 \mathrm{~h}$ incubation at $37^{\circ} \mathrm{C}$, the microtiter wells were washed three times with PBS. Adherent cells were then fixed with $200 \mu \mathrm{l}$ of $100 \%$ ethanol for $10 \mathrm{~min}$. The ethanol was removed and the wells were air dried for $2 \mathrm{~min}$. Adherent cells were stained for 2 min with $200 \mu \mathrm{l}$ of $0.41 \%$ crystal violet ( $\mathrm{w} / \mathrm{v}$ in $12 \%$ ethanol), then washed three times with PBS. The wells were allowed to dry and then eluted with ethanol. Absorbance readings were made at $595 \mathrm{~nm}$ using a SpectraMax M5 microplate spectrophotometer system (Molecular Devices, Sunnyvale, CA, USA). Experiments were performed in triplicate and three independent experiments were performed for each of these assays.

\section{Transmission electron microscopy}

A $\log$ phase culture of $A$. baumannii and $S$. aureus in separate tubes containing LB broth was split into $1.5 \mathrm{ml}$ aliquots. The cells were collected by centrifugation $(10000 \times \mathrm{g}, 5 \mathrm{~min})$ and resuspended in PBS (SigmaAldrich, St. Louis, MO, USA). Four samples were prepared; two untreated, two treated with BSLR (4X MIC). The samples were incubated at $37^{\circ} \mathrm{C}$ for $3 \mathrm{~h}$. The cells were collected by centrifugation $(10000 \times \mathrm{g}, 5 \mathrm{~min})$ to aspirate the supernates. To fix the cells, $4 \%$ glutaraldehyde was added to the pellet and the samples were incubated at $4^{\circ} \mathrm{C}$ for $1 \mathrm{~h}$. The cells were collected by centrifugation $(10000 \mathrm{rpm}$, $5 \mathrm{~min}$ ) and washed twice with $0.1 \mathrm{M}$ phosphate buffer. To postfix the cells, $1 \%$ osmium tetraoxide was added and the samples were left at room temperature for $1 \mathrm{~h}$. The samples were dehydrated with graded ethanol solutions $(50 \%$ ethanol for $15 \mathrm{~min}, 70 \%$ ethanol for $15 \mathrm{~min}$, 95\% ethanol for $15 \mathrm{~min}$, and $100 \%$ ethanol for $30 \mathrm{~min}$ ), embedded in epon and left to polymerize for $24 \mathrm{hrs}$. From each sample 10 thin slices (approximately $100 \mathrm{~nm}$ ) were cut with Leica ultra cut UCT (Leica, Buffalo grove, IL, USA). Each of these sections was examined with a JEOL 1400 transmission electron microscope (JEOL, Peabody, MA, USA).

\section{Abbreviations}

BS: Biosurfactants; MDR: Multidrug-resistant; MRSA: Methicillin resistant Staphylococcus aureus; EPS: Extracellular polysaccharide; MBEC: Minimum biofilm eradication concentration.

\section{Competing interests}

The authors declare that they have no competing interests.

\section{Authors' contributions}

KS designed and developed the assays for adhesion, biofilm inhibition and dispersion. KS also drafted the manuscript. XF carried out the antimicrobial and toxicity assays. SP and RP isolated the BS and performed the oil spreading assay. CP conceived of the study, participated in its design and coordination, and also drafted the manuscript. All authors read and approved the final manuscript.

\section{Acknowledgments}

The findings and opinions expressed herein belong to the authors and do not necessarily reflect the official views of the WRAIR, the U.S. Army, or the Department of Defense. This work was supported by a Defense Medical Research and Development Program (DMRDP) funding awarded to Dr. Chrysanthi Paranavitana. The authors would like to thank Ms. Amy Michels for editing the manuscript and Mr. Edward A. Asafo-Adjei for helping with electron microscopy experiments.

Received: 1 April 2014 Accepted: 27 June 2014

Published: 14 August 2014

\section{References}

1. Van Hamme JD, Singh A, Ward OP: Physiological aspects. Part 1 in a series of papers devoted to surfactants in microbiology and biotechnology. Biotechnol Adv 2006, 24(6):604-620.

2. Cameotra SS, Makkar RS, Kaur J, Mehta S: Synthesis of biosurfactants and their advantages to microorganisms and mankind. Biosurfaces 2010, 672:261-280.

3. Singh P, Cameotra SS: Potential applications of microbial surfactants in biomedical sciences. Trends Biotechnol 2004, 22(3):142-146.

4. Ahimou F, Jacques $P$, Deleu M: Surfactin and iturin A effects on bacillus subtilis surface hydrophobicity. Enzyme Microb Technol 2000, 27(10):749-754.

5. Arutchelvi II, Bhaduri S, Uppara PV, Doble M: Mannosylerythritol lipids: a review. J Ind Microbiol Biotechnol 2008, 35(12):1559-1570,

6. Benincasa M, Abalos A, Oliveira I, Manresa A: Chemical structure, surface properties and biological activities of the biosurfactant produced by Pseudomonas aeruginosa LBI from soapstock. Antonie Van Leeuwenhoek 2004, 85(1):1-8.

7. Rodrigues L, van der Mei H, Banat IM, Teixeira J, Oliveira R: Inhibition of microbial adhesion to silicone rubber treated with biosurfactant from Streptococcus thermophilus A. FEMS Immunol Med Microbiol 2006, 46(1):107-112.

8. Rodrigues $L$, van der Mei $H$, Teixeira JA, Oliveira R: Biosurfactant from Lactococcus lactis 53 inhibits microbial adhesion on silicone rubber. Appl Microbiol Biotechnol 2004, 66(3):306-311.

9. Rodrigues $L$, van der Mei HC, Teixeira J, Oliveira R: Influence of biosurfactants from probiotic bacteria on formation of biofilms on voice prostheses. Appl Environ Microbiol 2004, 70(7):4408-4410.

10. Velraeds MMC, van der Mei HC, Reid G, Busscher HJ: Physicochemical and biochemical characterization of biosurfactants released by Lactobacillus strains. Colloids Surf B Biointerfaces 1996, 8(1-2):51-61.

11. Rodrigues $L$, Banat IM, Teixeira J, Oliveira R: Biosurfactants: potential applications in medicine. J Antimicrob Chemother 2006, 57(4):609-618.

12. Velraeds MM, van der Mei HC, Reid G, Busscher HJ: Inhibition of initial adhesion of uropathogenic Enterococcus faecalis by biosurfactants from Lactobacillus isolates. Appl Environ Microbiol 1996, 62(6):1958-1963.

13. Costerton JW, Lewandowski Z, Caldwell DE, Korber DR, Lappin-Scott HM: Microbial biofilms. Annu Rev Microbiol 1995, 49:711-745.

14. Anderl JN, Franklin MJ, Stewart PS: Role of antibiotic penetration limitation in Klebsiella pneumoniae biofilm resistance to ampicillin and ciprofloxacin. Antimicrob Agents Chemother 2000, 44(7):1818-1824.

15. Fux CA, Costerton JW, Stewart PS, Stoodley P: Survival strategies of infectious biofilms. Trends Microbiol 2005, 13(1):34-40.

16. Fusetani N: Biofouling and antifouling. Nat Prod Rep 2004, 21(1):94-104.

17. Qian $P Y, X u Y$, Fusetani $N$ : Natural products as antifouling compounds: recent progress and future perspectives. Biofouling 2010, 26(2):223-234.

18. Tahmourespour A, Salehi R, Kermanshahi RK, Eslami G: The anti-biofouling effect of Lactobacillus fermentum-derived biosurfactant against Streptococcus mutans. Biofouling 2011, 27(4):385-392.

19. Dusane DH, Nancharaiah YV, Zinjarde SS, Venugopalan VP: Rhamnolipid mediated disruption of marine Bacillus pumilus biofilms. Colloids Surf $B$ Biointerfaces 2010, 81(1):242-248.

20. Dusane DH, Rajput JK, Kumar AR, Nancharaiah W, Venugopalan VP, Zinjarde SS: Disruption of fungal and bacterial biofilms by lauroyl glucose. Lett Appl Microbiol 2008, 47(5):374-379.

21. Rivardo F, Turner RJ, Allegrone G, Ceri H, Martinotti MG: Anti-adhesion activity of two biosurfactants produced by Bacillus spp. prevents biofilm formation of human bacterial pathogens. Appl Microbiol Biotechnol 2009, 83(3):541-553. 
22. Irie Y, OToole GA, Yuk MH: Pseudomonas aeruginosa rhamnolipids disperse Bordetella bronchiseptica biofilms. FEMS Microbiol Lett 2005, 250(2):237-243.

23. Rasmussen TB, Givskov M: Quorum-sensing inhibitors as anti-pathogenic drugs. Int J Med Microbiol 2006, 296(2-3):149-161.

24. Valle J, Da Re S, Henry N, Fontaine T, Balestrino D, Latour-Lambert P, Ghigo JM: Broad-spectrum biofilm inhibition by a secreted bacterial polysaccharide. Proc Natl Acad Sci U S A 2006, 103(33):12558-12563.

25. Walencka E, Rozalska S, Sadowska B, Rozalska B: The influence of Lactobacillus acidophilus-derived surfactants on staphylococcal adhesion and biofilm formation. Folia Microbiol 2008, 53(1):61-66.

26. Busscher HJ, van Hoogmoed CG, Geertsema-Doornbusch GI, van der Kuij|-Booij M, van der Mei HC: Streptococcus thermophilus and its biosurfactants inhibit adhesion by Candida spp. on silicone rubber. Appl Environ Microbiol 1997, 63(10):3810-3817.

27. Gan BS, Kim J, Reid G, Cadieux P, Howard JC: Lactobacillus fermentum RC-14 inhibits Staphylococcus aureus infection of surgical implants in rats. J Infect Dis 2002, 185(9):1369-1372.

28. Rodrigues $L R$, Teixeira $J A$, van der Mei $H C$, Oliveira R: Isolation and partial characterization of a biosurfactant produced by Streptococcus thermophilus A. Colloids Surf B Biointerfaces 2006, 53(1):105-112.

29. Rodrigues LR, Teixeira JA, van der Mei HC, Oliveira R: Physicochemical and functional characterization of a biosurfactant produced by Lactococcus lactis 53. Colloids Surf B Biointerfaces 2006, 49(1):79-86.

30. Singh A, Van Hamme JD, Ward OP: Surfactants in microbiology and biotechnology: Part 2. Application aspects. Biotechnol Adv 2007, 25(1):99-121.

31. Satpute S, Bhawsar BD, Dhakephalkar PK, Chopade BA: Assessment of different screening methods for selecting biosurfactant producing marine bacteria. IJMS 2008, 37(3):243-250.

32. Walter V, Syldatk C, Hausmann R: Screening concepts for the isolation of biosurfactant producing microorganisms. Adv Exp Med Biol 2010, 672:1-13

33. Gudina EJ, Rocha V, Teixeira JA, Rodrigues LR: Antimicrobial and antiadhesive properties of a biosurfactant isolated from Lactobacillus paracasei ssp. paracasei A20. Lett Appl Microbiol 2010, 50(4):419-424.

34. Sriram MI, Kalishwaralal K, Deepak V, Gracerosepat R, Srisakthi K, Gurunathan S: Biofilm inhibition and antimicrobial action of lipopeptide biosurfactant produced by heavy metal tolerant strain Bacillus cereus NK1. Colloids Surf B Biointerfaces 2011, 85(2):174-181.

35. Mukherjee S, Das P, Sivapathasekaran C, Sen R: Antimicrobial biosurfactants from marine Bacillus circulans: extracellular synthesis and purification. Lett Appl Microbiol 2009, 48(3):281-288.

36. Nitschke M, Costa SGVAO: Biosurfactants in food industry. Trends Food SC Technol 2007, 18(5):252-259.

37. Falagas ME, Makris GC: Probiotic bacteria and biosurfactants for nosocomial infection control: a hypothesis. J Hosp Infect 2009, 71(4):301-306.

38. Sambanthamoorthy K, Sloup RE, Parashar V, Smith JM, Kim EE, Semmelhack $M F$, Neiditch MB, Waters CM: Identification of small molecules that antagonize diguanylate cyclase enzymes to inhibit biofilm formation. Antimicrob Agents Chemother 2012, 56(10):5202-5211.

39. Sambanthamoorthy $\mathrm{K}$, Schwartz A, Nagarajan V, Elasri MO: The role of msa in staphylococcus aureus biofilm formation. BMC Microbiol 2008, 8:221.

40. Feng X, Sambanthamoorthy K, Palys T, Paranavitana C: The human antimicrobial peptide LL-37 and its fragments possess both antimicrobial and antibiofilm activities against multidrug-resistant Acinetobacter baumannii. Peptides 2013, 49:131-137.

doi:10.1186/1471-2180-14-197

Cite this article as: Sambanthamoorthy et al: Antimicrobial and antibiofilm potential of biosurfactants isolated from lactobacilli against multi-drug-resistant pathogens. BMC Microbiology 2014 14:197.

\section{Submit your next manuscript to BioMed Central and take full advantage of:}

- Convenient online submission

- Thorough peer review

- No space constraints or color figure charges

- Immediate publication on acceptance

- Inclusion in PubMed, CAS, Scopus and Google Scholar

- Research which is freely available for redistribution

Submit your manuscript at www.biomedcentral.com/submit
Ciomed Central 